Saint Louis University School of Law

Scholarship Commons

All Faculty Scholarship

2020

\title{
The undeserving rich: can they be redeemed? Policy options for curbing illegal wealth
}

James F. Gilsinan

Saint Louis University-Department of Political Science

James E. Fisher

Saint Louis University - Richard A. Chaifetz School of Business

Muhammad Islam

Saint Louis University - Richard A. Chaifetz School of Business

Henry Ordower

Saint Louis University School of Law

Wassim Shahin

Lebanese American University-School of Business

Follow this and additional works at: https://scholarship.law.slu.edu/faculty

Part of the Criminal Law Commons, Other Legal Studies Commons, and the Social Justice Commons

\section{Recommended Citation}

Gilsinan, James and Fisher, James E. and Islam, Muhammad and Ordower, Henry and Shahin, Wassim, The undeserving rich: can they be redeemed? Policy options for curbing illegal wealth (May 17, 2021). Journal of Financial Crime, v. 27 no. 4, 2020, Saint Louis U. Legal Studies Research Paper No. 2020-39.

This Abstract is brought to you for free and open access by Scholarship Commons. It has been accepted for inclusion in All Faculty Scholarship by an authorized administrator of Scholarship Commons. For more information, please contact erika.cohn@slu.edu, ingah.daviscrawford@slu.edu. 


\section{The undeserving rich: can they be redeemed? Policy options for curbing illegal wealth}

Journal of Financial Crime, v. 27 no. 4, 2020

Saint Louis U. Legal Studies Research Paper No. 2020-39

James F. Gilsinan

Department of Political Science, Saint Louis University

James E. Fisher

Saint Louis University - Richard A. Chaifetz School of Business

Muhammad Islam

Saint Louis University - Richard A. Chaifetz School of Business

Henry Ordower

Saint Louis University - School of Law

Wassim Shahin

Lebanese American University-School of Business

\section{$\underline{\text { Abstract }}$}

Purpose - The purpose of this study is to examine the efficacy of various policy options for curbing the accumulation of illegal wealth and suggest ways to close the increasing wealth inequality gap.

Design/methodology/approach - The paper begins with a historical/literary analysis of the place of wealth in American Society and the ambivalent cultural attitudes toward wealth. Different policy approaches that seek to limit wealth inequality and the illegal accumulation of wealth are then examined. Finally, the current policy climate in the USA is reviewed to determine the likelihood of meaningful reform.

Findings - In Europe, the BASEL accords show promise for curbing the illegal accumulation of wealth by politically exposed persons. In the USA, tax reform efforts can close the wealth gap, but the current political landscape makes meaningful reform challenging particularly given the increasing use of "dark" money to influence elections. 
Research limitations/implications - Because financial reform is a moving target in both Europe and the USA, subject to the ebb and flow of political forces, it is difficult to predict what major reforms will be possible.

Practical implications - Without meaningful reform, an increase in populist movements can be expected (e.g. Brexit and Trump) with an overall, long-term negative impact on democratic capitalism.

Social implications - The wealth gap and the sense that the system is rigged against the common people will result in increasing political turmoil.

Originality/value - Combining literary/historical analysis with the analysis of current policy interventions provides a set of tools not usually used in the examination of financial crimes.

Keywords: Financial reform, Politically exposed persons, Closing the wealth gap, Dark Money, Illegal wealth accumulation

\section{Suggested Citation:}

Gilsinan, James and Fisher, James E. and Islam, Muhammad and Ordower, Henry and Shahin, Wassim, The undeserving rich: can they be redeemed? Policy options for curbing illegal wealth. Journal of Financial Crime, v. 27 no. 4, 2020, Saint Louis U. Legal Studies Research Paper No. 2020-39. 